\title{
ANTIVIRAL EFFECT OF CERIUM DIOXIDE NANOPARTICLES ON THE MODEL OF THE CAUSATIVE AGENT OF BOVINE VIRAL DIARRHEA
}

\author{
B.T. Stegniy ${ }^{1}$, O.A. Demchenko', O.M. Korneykov ${ }^{1}$, \\ M.Yu. Stegniy ${ }^{1}$, A.Yu. Oleshko ${ }^{1}$, O.B. Korneikova ${ }^{1}$, \\ I.V. Korovin', L.P. Babenko', M.Ya. Spivak ${ }^{2}$ \\ ${ }^{l}$ National Research Center «Institute of Experimental and Clinical Veterinary Medicine» \\ 83 Pushkinska Str., Kharkiv, 61083, Ukraine \\ ${ }^{2}$ Zabolotny Institute of Microbiology and Virology, NAS of Ukraine \\ 154 Acad. Zabolotny Str., Kyiv, 03143, Ukraine \\ e-mail:n.spivak@ukr.net
}

Cerium dioxide nanoparticles $\left(\mathrm{CeO}_{2}\right)$ have a wide range of biological properties, including antiviral activity. Preparations based on cerium oxide nanoparticles can be effective against animal RNA viruses, which have the greatest epizootic significance for Ukraine and potentially against human viruses, including SARS-CoV-2. In our studies, we determined the effect of cerium dioxide nanoparticles on bovine viral diarrhea virus $(B V D V)$, a pestivirus that is the etiological agent of bovine viral diarrhea. To determine the antiviral efficacy of $\mathrm{CeO}$, a cytopathogenic strain of $B V D V$ " $B K-1$ " was used as an etiological agent of bovine viral diarrhea, which induces a cytopathic effect on cow embryo lungs (CEL) cell culture. When evaluating the antiviral efficacy of $\mathrm{CeO}_{2}$, it was determined that the MPC for CEL cell culture is $0.057 \mu \mathrm{g} / \mathrm{cm}^{3}$, and the $\mathrm{CC}_{50}$ is $0.077 \mu \mathrm{g} / \mathrm{cm}^{3}$. The antiviral activity of $\mathrm{CeO}_{2}$ was evaluated by the $\mathrm{IC}_{50}$ index, which was $0.036 \mu \mathrm{g} / \mathrm{cm}^{3}$ and the selectivity index, which after co-administration of $\mathrm{CeO}_{2}$ with $\mathrm{BVDV}$ was 2.14. There was a decrease in the titer of infectious activity of the virus during treatment with $\mathrm{CeO}_{2}$ by $2.09 \mathrm{lg} \mathrm{TCD}{ }_{50} / \mathrm{cm}^{3}$.

Keywords: Bovine viral diarrhea virus, nanoparticles, cerium dioxide, bovine fetal lung (BFL) cell culture, antiviral activity.

Given the problem of significant prevalence in the world of viral etiology diseases caused by pathogens that have significant homology to animal viruses, the fight against them requires new approaches. The most resonant in this aspect were the diseases of severe acute respiratory syndrome or atypical pneumonia (SARS-CoV, 2002-2003) [1], Middle Eastern coronavirus respiratory syndrome (MERS-CoV, 2012-2015) [2] and coronavirus COVID-19 infection (SARS-CoV-2, pandemic since 2019) [3].

That is why the availability of highly effective therapeutic agents with proven antiviral activity, which would stop the spread of viruses, their possible emergence, and the main reduction in mortality from the disease is a topical issue today [4-7].

In order to determine the effectiveness of a therapeutic agent, their investigations is carried out on biological models of in vitro cell cultures [8-11], which allows to obtain preliminary data for further clinical study of substances. Therapeutic drug should have a pronounced antiviral effect, moderate toxicity, if possible should affect the non-specific part of the immune system, and be available.

Given the complex epidemiological situation around the world regarding COVID-19 pandemic, working with viral pathogens that pose a threat to humans is associated with significant biological risks, so the use of animal viruses for studying the antiviral efficacy of various substances will minimize these problems.

Taking into account considerable relevance of the problem of viral pneumo-enteritis of cattle to the livestock of Ukraine and the EU [12, 13], introduction of new methodological approaches to combating and eliminating viral pathogens, which circulates in cattle herds, acquires special significance. One of the most etiologically meaningful pathogens, which causes cattle disease with respiratory syndrome, is a bovine viral diarrhea virus (BVDV) $[14,15]$. In addition, the defined virus is the most common contamination of 
biological preparations (cell cultures, fetal bovine serum, embryos, vaccines, etc.) $[16,17]$. The greatest importance in supporting the endemicity of the cattle regarding BVDV has persistently infected calves born by cows infected with noncytopathogenic biotype in the early timing of pregnancy $[18,19]$.

In addition to the immunosuppressive state of infected animals, which leads to secondary infectious and non-infectious diseases in cattle [20], the virus may cause damage to the respiratory tract, abortion, infertility, mucous diseases, thrombocytopenia and acute inflammation of the gastrointestinal tract [21, 22].

Based on the above, the in vitro study of cerium dioxide nanoparticles antiviral effectiveness against viral animal pathogens, in particular BVDV, will allow to get the first responses about the substance effectiveness against viruses and determine the expediency of further research in this direction.

Hypothesis. Preparations based on cerium dioxide nanoparticles can be effective against RNA animal viruses that have the largest epizootic value for Ukraine (pestivirus, causative agent of BVDV) and potentially against human viruses, including SARS-COV-2.

The aim of our research was to establish the antiviral activity of cerium dioxide nanoparticles on a model of pestivirus of cattle-BVDV.

\section{Materials and Methods}

Strain of virus and cell culture

BVDV causes viral diarrhea disease - mucous disease (VD-MD). This single-chain RNAcontaining virus with a diameter of $40-60 \mathrm{~nm}$, is a representative of the Pestivirus genus of Flaviviridae family. The disease in cattle is caused by two genotypes of the virus (BVDV1 and BVDV2), each of them have cytopathic and non-citopathic biotypes [21].

BVDV is largely manifested by crosslinking, that is, reproduced in various organs and tissues of cattle, especially cells that are rapidly multiplied embryo cells, breeding organs, respiration and immune system, and gastrointestinal tract. "VK1" BVDV strain (obtained from the Depositary of the National Scientific Center "Institute of Experimental and Clinical Veterinary Medicine" (NSC "IECVM"), Kharkiv) was used in the work after the restoration of infectious activity during 6 consecutive passages.

Cow embryo lungs (CEL) cell culture sensitive to the viral diarrhea virus, obtained from the cryobank of NSC "IECVM" was used in the work. The initial concentration of the cells was $3 \times 10^{5}$ cells $/ \mathrm{cm}^{3}$; DMEM and 199 (LLC "RE Veterinary Medicine", Ukraine) were used as a growing nutrient media in equal ratios with $10 \%$ of the native inactivated cattle serum and antibiotics (penicillin 100 units $/ \mathrm{cm}^{3}$ and streptomycin $\left.100 \mu \mathrm{g} / \mathrm{cm}^{3}\right)$ [23].

Identification and establishment of virus infectious activity

According to the results of the virus reproduction on the sensitive cell culture (typical cytopathic effect), the virus-containing material was obtained, the presence of BVDV was confirmed by the immunofluorescence method in accordance with the manufacturer's instruction (LLC "RE Veterinary Medicine", Kharkiv) and its genetic material - by means of a polymerase chain reaction (PCR) using primer systems 324 (ATGCCC $(T / A)$ TAGTAGGACTA) and 326 (TCAACTCCATGTGCCATGTAC) [24, 25]. The establishment of infectious activity of BVDV strain "VK-1" (before and after the treatment with $\mathrm{CeO}_{2}$ ) was carried out by detecting a cytopathic effect (CPE) in infected culture of CEL. The calculation of the virus infectivity titre was carried out according to Rid and Mench [26] method and was expressed in tissue cytopathic doses of $1.0 \mathrm{~cm}^{3}$, causing a loss of $50 \%$ of infected cell culture $\left(\mathrm{TCD}_{50} / \mathrm{cm}^{3}\right)$.

\section{Obtaining of cerium dioxide nanoparticles}

Cerium dioxide aqueous solution obtaining was performed at the Zabolotny Institute of Microbiology and Virology of the NAS of Ukraine by dissolving of $3.73 \mathrm{~g}$ of cerium chloride heptahydrate (III) and $2.0 \mathrm{~g}$ of citric acid in $20 \mathrm{~mL}$ of distilled water. This solution with a continuous mixing was rapidly added to an aqueous ammonia solution made by mixing of $10 \mathrm{~g}$ of concentrated ammonia ("Sigma", USA) and $100 \mathrm{~mL}$ of distilled water. The solution was stirred for 5 hours, followed by boiling, resulting in obtaining of $100 \mathrm{~mL}$ of $0.1 \mathrm{M}$ cerium dioxide nanoparticles.

\section{Investigation of cerium dioxide nanoparticles}

The optical spectrum of cerium dioxide was determined on the OceanOptics QE 65000 spectrometer using a single-beam circuit. Radiation was provided by deuterium halogen lamp DH 2000 and xenon lamp HPX 2000. Optical absorption spectra were further used to calculate the energy of $E G$ of $\mathrm{CeO}_{2}$ nanoparticles. The size of cerium dioxide nanoparticles was determined by the method of transmission electron microscopy (TEM) on electron microscope LEO 912 AB Omega at $100 \mathrm{kV}$. The hydrodynamic diameter of citratecoated $\mathrm{CeO}_{2}$ was measured by a dynamic light 
scattering method (DLS) using Malvern Zetasizer Nano ZS analyzer. The sol was diluted with distilled water before measuring. An analysis of powder X-ray diffraction (XRD) of cerium nanoparticles obtained by centrifugation of sol was performed using Rigaku D/MAX 2500 diffractometer $\left(\mathrm{CuK}_{\mathrm{a}}\right.$ radiation, an instrumental extension of $0.10 \pm 0.012 q)$. The speed of the goniometer rotation was $2^{\circ} 2 \mathrm{q} / \mathrm{min}$. The size of crystallite (D) of nanocrystalline cerium was calculated according to the Scherrer formula, where the anisotropy coefficient was equal to 1 . Linear profiles for reflections (111) and (200) were corrected according to the Voigt profile.

Investigation of cytotoxic concentration $\left(\mathrm{CC}_{50}\right)$ of cerium dioxide

Determination of $\mathrm{CC}_{50}$ of the preparation that contained $\mathrm{CeO}_{2}$ was carried out on CEL cell culture at its final concentration of $0.172 \mu \mathrm{g} / \mathrm{cm}^{3}$, $0.086 \mu \mathrm{g} / \mathrm{cm}^{3}, 0.057 \mu \mathrm{g} / \mathrm{cm}^{3}, 0.043 \mu \mathrm{g} / \mathrm{cm}^{3}$, and $0.034 \mu \mathrm{g} / \mathrm{cm}^{3}$. Working dilutions of the preparation of $\mathrm{CeO}_{2}$ were prepared using supporting nutrient medium 199. Determination of the cytotoxic action of the preparation was carried out by removing a growth nutrient medium from a formed monolayer and replacing it to supporting, which contained the corresponding concentration of $\mathrm{CeO}_{2} .5$ samples of CEL cell culture were used for studying of each dilution of the drug.

Cell culture (5 samples) with a formed monolayer on a supporting nutrient medium without $\mathrm{CeO}_{2}$ was used as a control. The cytotoxic effect of the various concentrations of cerium dioxide was evaluated visually after 24,48 and 72 hours using inverted microscope, taking into account changes in cell morphology and violation of monolayer integrity. The integrity of cell membranes was determined using $0.2 \%$ solution of trypan blue (in the absence of cell color) [23]. The degree of manifestation of $\mathrm{CeO}_{2}$ cytotoxic effect was evaluated in crosses (from " ++++ " to " $3 / 4$ "), where "3/4" - a complete absence of cells degeneration, "+" - violation of cells morphology and integrity of no more than $25 \%$ of the monolayer, "++" no more than $50 \%$ of cells monolayer," $+++"$ - no more than $75 \%$ of cells monolayer and "++++" complete degeneration of cells and destruction of the monolayer. $\mathrm{CC}_{50}$ of $\mathrm{CeO}_{2}$ was determined as its concentration, which led to the destruction of $50 \%$ of cells monolayer due to cytotoxicity.

To the study the antiviral efficacy, we used $\mathrm{CeO}_{2}$ in concentrations (taking into account the maximum allowable concentration) which did not cause cell death in the monolayer of the CEL cell culture and did not cause morphological changes in cells.

Determination of antiviral efficacy of cerium dioxide nanoparticles on the model of BVDV

After determining the maximum allowable concentration of $\mathrm{CeO}_{2}$, non-toxic for CEL cell culture, the antiviral efficacy of the drug was determined by applying of its different concentrations simultaneously with BVDV strain "VK-1" after their co-incubation [27]. $100 \mathrm{TCD}_{50} / \mathrm{cm}^{3}$ of BVDV were used to standardize the viral suspension and infect cells monolayer [28]. "VK-1" strain was previously treated with different concentrations of $\mathrm{CeO}_{2}$ in a ratio of $1: 1$. For this purpose, a mixture of different concentrations of $\mathrm{CeO}_{2}$ and BVDV strain "VK-1" with a final infectious activity of $100 \mathrm{TCD}_{50} / \mathrm{cm}^{3}$ was prepared and then incubated for 40 minutes at a temperature of $37{ }^{\circ} \mathrm{C}$. The growth medium was removed from CEL cell culture with the $100 \%$ monolayer formed, monolayer was washed three times with DMEM medium, and then 1:10 of the drug-virus mixture volume was added. The samples were incubated for 60 minutes at $37{ }^{\circ} \mathrm{C}$, and then the virus-drug mixture was removed from the monolayer, then it was washed three times with DMEM medium and a growth support medium was added. Incubation of samples was performed at a temperature of $37^{\circ} \mathrm{C}$.

We used 5 samples of CEL cell culture for each dilution of the drug. The following control samples $(n=5)$ were used to determine the efficiency of $\mathrm{CeO}_{2}$ at different concentrations: control of CEL cell culture on maintenance medium (CC); control of $100 \mathrm{TCD}_{50} / \mathrm{cm}^{3}$ of BVDV strain "VK-1" on CEL cell culture (VC); control of cytotoxic effect of the corresponding concentrations of $\mathrm{CeO}_{2}$ on CEL cell culture.

The results of the study were recorded according to the results of $100 \%$ CPE of BVDV strain "VK-1" in CEL cell culture monolayer in samples of $100 \mathrm{TCD}_{50} / \mathrm{cm}^{3}$ virus control (VC) [29].

Determination of the antiviral efficacy of $\mathrm{CeO}_{2}$ was performed by establishing $\mathrm{IC}_{50}-$ the concentration of the drug that inhibits virusinduced CPE in $50 \%$ of cells monolayer [30]. The state of the monolayer, its integrity, changes in cell morphology in the appropriate controls and test samples containing different concentrations of the drug were taken into account. Evaluation of virus CPE, by analogy with the cytotoxic concentration, was performed in crosses (from "++++" to " $3 / 4$ "). Cell viability was determined by the integrity of 
their membrane using vital staining with $0.2 \%$ of trypan blue solution (no cell staining).

After cytotoxic and inhibitory concentrations of $\mathrm{CeO}_{2}$ investigation the selectivity index (SI) was calculated as the ratio of $\mathrm{CC}_{50}$ to $\mathrm{IC}_{50}$ to determine the antiviral efficacy of the drug.

\section{Statistical data processing}

Statistical processing of data from preclinical studies was performed by nonparametric analysis (presented in the form of medians and interquartile intervals of the sample) [31, 32]. Data were visualized in boxplot graphs through nonparametric Kruskal-Wallis ANOVA analysis and median test. Data processing was performed using the "Statistica" software and online calculator of $\mathrm{CC}_{50}$ and $\mathrm{IC}_{50}$ AAT Bioquest [33].

\section{Results}

Identification and restoration of infectious activity of bovine viral diarrhea virus

Restoration of biological properties of BVDV strain "VK-1" after storage at a temperature of minus $70{ }^{\circ} \mathrm{C}$ in the Depository of NSC "IECVM" was carried out on CEL cell culture during 6 consecutive passages.

The presence of genetic material of BVDV in aliquots after storage in the Depository of NSC "IECVM" and after restoration of its biological properties during 6 consecutive passages was confirmed by PCR (the formation of amplicon at 324/326 base pairs was observed) and its antigens - by immunofluorescence reaction (a specific luminescent glow of antigens of BVDV

Table 1

Cytotoxicity of cerium dioxide nanoparticles on CEL cell culture

\begin{tabular}{|l|c|c|}
\hline Concentration of $\mathbf{C e O}_{2}, \boldsymbol{\mu g} / \mathbf{c m}^{3}$ & Indicator & Affected cells, $\%$ \\
\hline \multirow{2}{*}{0.172} & $\mathrm{M} \pm \mathrm{m}^{*}$ & $70.0 \pm 5.00$ \\
\cline { 2 - 3 } & $\mathrm{Q}_{2}\left[\mathrm{Q}_{1}-\mathrm{Q}_{3}\right]^{* *}$ & $75.0^{* * *}$ \\
\hline \multirow{2}{*}{0.086} & $\mathrm{M}^{*} \mathrm{~m}^{*}$ & $50.0 \pm 7.91$ \\
\cline { 2 - 3 } & $\mathrm{Q}_{2}\left[\mathrm{Q}_{1}-\mathrm{Q}_{3}\right]^{* *}$ & $50.0 * * *$ \\
\cline { 2 - 3 } 0.057 & $\mathrm{M} \pm \mathrm{m}^{*}$ & $4.0 \pm 2.45$ \\
\cline { 2 - 3 } & $\mathrm{Q}_{2}\left[\mathrm{Q}_{1}-\mathrm{Q}_{3}\right]^{* *}$ & $0[0-10.0]$ \\
\cline { 2 - 3 } & $\mathrm{M}^{*} \pm \mathrm{m}^{*}$ & 0 \\
\hline \multirow{2}{*}{0.034} & $\mathrm{Q}_{2}\left[\mathrm{Q}_{1}-\mathrm{Q}_{3}\right]^{* *}$ & 0 \\
\cline { 2 - 3 } & $\mathrm{M}_{2} \pm \mathrm{m}^{*}$ & 0 \\
\hline
\end{tabular}

$* \mathrm{M} \pm \mathrm{m}$, where $\mathrm{M}$ is the mean value, $\mathrm{m}$ is the arithmetic mean error; ** $\mathrm{Q}_{2}\left[\mathrm{Q}_{1}-\mathrm{Q}_{3}\right]$, where $\mathrm{Q}_{2}$ is the median $(50 \%$ of the sample), where $\mathrm{Q}_{1}$ and $\mathrm{Q}_{3}$ are the lower and upper quartiles $\left(25 \%\right.$ and $75 \%$ of the sample); $* * * \mathrm{Q}_{2}$ corresponds to the interval $\left[\mathrm{Q}_{1}-\mathrm{Q}_{3}\right]$.

A

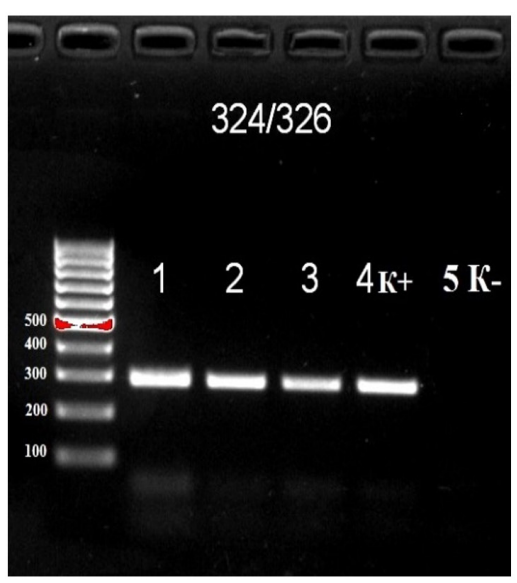

B

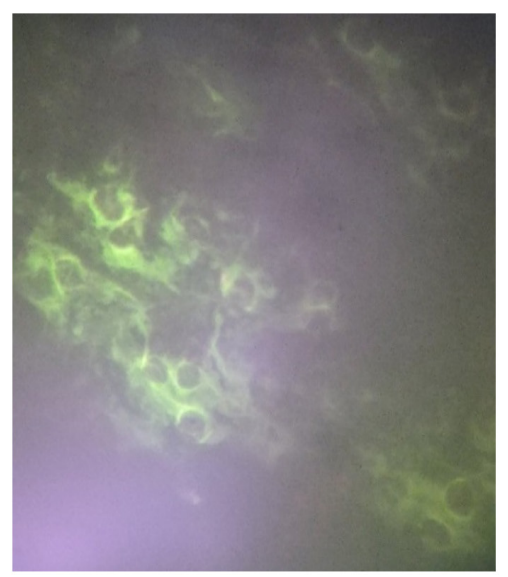

Fig. 1. Identification of BVDV in the test material at 6 passages by immunofluorescence reaction (a), as well as before $1^{\text {st }}$ and after $6^{\text {th }}$ passages by PCR (b). Note: 1 - after storage in the Depository of NSC "IECVM"; 2, 3 - after 6 passages on the CEL cell culture; $4 \mathrm{~K}+-$ positive control; $5 \mathrm{~K}-$ negative control. 
in the infected monolayer of CEL cell culture was observed after treatment of the test sample with specific immunofluorochrome) (Fig. 1).

According to the results of the restoration of BVDV biological properties in CEL cell culture, it was found that the titer of infectious activity of the pathogen at the level of 6 passages was $6.87 \mathrm{lg} \mathrm{TCD}_{50} / \mathrm{cm}^{3}$. This indicator was chosen as the starting point in the study of cerium dioxide nanoparticles efficiency. Taking into account the infectivity titer of BVDV strain "VK-1" on CEL cell culture, the standard dose of infection was determined when studying the antiviral efficacy of $\mathrm{CeO}_{2}\left(100 \mathrm{TCD}_{50} / \mathrm{cm}^{3}\right)$.

Determination of cytotoxic action of cerium dioxide nanoparticles

Determination of cytotoxic effect of cerium dioxide nanoparticles was performed on CEL cell culture, using the final concentration of the drug from $0.172 \mu \mathrm{g} / \mathrm{cm}^{3}$ to $0.034 \mu \mathrm{g} / \mathrm{cm}^{3}$ (Table 1).

According to the results of studying the cytotoxic effect of $\mathrm{CeO}_{2}$ on CEL cell culture, it was determined that the use of the drug in a final concentration of $0.172 \mu \mathrm{g} / \mathrm{cm}^{3}$ led to changes in morphology and reduced viability of $50-75 \%$ of cells. The use of the drug at a final concentration of $0.086 \mu \mathrm{g} / \mathrm{cm}^{3}$ was characterized by changes in morphology and disruption of membrane integrity of $25-75 \%$ of cells. Instead, the use of cerium dioxide nanoparticles in the nutrient medium at a final concentration of $0.057 \mu \mathrm{g} / \mathrm{cm}^{3}$ did not have a significant effect on cell morphology and the integrity of the monolayer of CEL cell culture.

Based on the results of the studies, the $\mathrm{CC}_{50}$ (Fig. 2) and the maximum allowable concentration
(MAC) of cerium dioxide nanoparticles were determined, this concentration did not affect cell viability and monolayer degeneration (preservation of cell monolayer at 90-100\%) and was $0.057 \mu \mathrm{g} / \mathrm{cm}^{3}$.

Visualization of data on the cytotoxic concentration of $\mathrm{CeO}_{2}$, which leads to the death of $50 \%$ of CEL cell culture monolayer was performed using non-parametric Kruskal-Wallis ANOVA analysis and median test.

The concentration of $\mathrm{CeO}_{2}$ that leads to the death of $50 \%$ of cells monolayer of CEL cell culture is $0.077 \mu \mathrm{g} / \mathrm{cm}^{3}$.

Determination of antiviral effect of cerium dioxide nanoparticles on BVDV model

It was found that $100 \%$ manifestation of the cytopathic effect of BVDV strain "VK-1" on CEL cell culture (control samples) was observed 24 hours after application of virus in $100 \mathrm{TCD}_{50} / \mathrm{cm}^{3}$. This time was chosen to take into account the results of experimental and control samples. During this time, the morphology of cells and the integrity of the monolayer of control samples of cell culture and control samples of determining the cytotoxicity of different concentrations of $\mathrm{CeO}_{2}$ remained unchanged.

The use of cerium dioxide nanoparticles at a final concentration of $0.057 \mu \mathrm{g} / \mathrm{cm}^{3}$ inhibited the manifestation of virus-induced CPE on CEL cell culture, maintaining cell morphology and monolayer integrity at 75.0-100.0\% (Table 2).

Further reduction of the final concentration of cerium dioxide to $0.043 \mu \mathrm{g} / \mathrm{cm}^{3}$ for virus treatment led to the preservation of morphology and viability of cells monolayer at the level of $50.0-100.0 \%$.

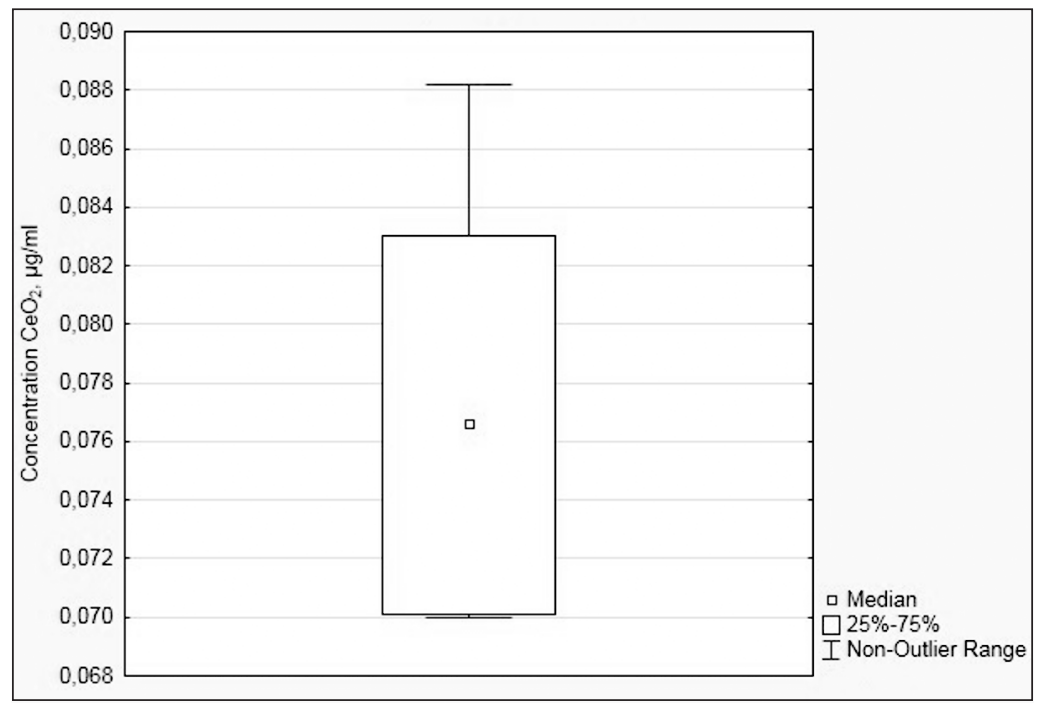

Fig. 2. Median and interquartile range of $\mathrm{CC}_{50}$ of $\mathrm{CeO}_{2}$ visualized through non-parametric Kruskal-Wallis ANOVA analysis and median test (boxplot) 
Table 2

The effectiveness of $\mathrm{CeO}_{2}$ in preventing the manifestation of $\mathrm{BVDV}$-induced cytopathic effect on CEL cell culture

\begin{tabular}{|l|c|c|}
\hline \multirow{2}{*}{ Concentration, $\mu \mathrm{g} / \mathrm{cm}^{3}$} & Indicator & Cells without changes in morphology and membrane integrity, \% \\
\hline \multirow{2}{*}{0.057} & $\mathrm{M} \pm \mathrm{m}^{*}$ & $90.0 \pm 6.12$ \\
\cline { 2 - 3 } & $\mathrm{Q}_{2}\left[\mathrm{Q}_{1}-\mathrm{Q}_{3}\right]^{* *}$ & $100.0[75.0-100.0]$ \\
\hline \multirow{2}{*}{0.043} & $\mathrm{M} \pm \mathrm{m}^{*}$ & $75.0 \pm 7.91$ \\
\cline { 2 - 3 } & $\mathrm{Q}_{2}\left[\mathrm{Q}_{1}-\mathrm{Q}_{3}\right]^{* *}$ & $75.0^{* * *}$ \\
\hline \multirow{2}{*}{0.034} & ${\mathrm{M} \pm \mathrm{m}^{*}}^{*}$ & $50.0 \pm 11.18$ \\
\cline { 2 - 3 } & $\mathrm{Q}_{2}\left[\mathrm{Q}_{1}-\mathrm{Q}_{3}\right]^{* *}$ & $50.0[25.0-75.0]$ \\
\hline
\end{tabular}

${ }^{*} \mathrm{M} \pm \mathrm{m}$, where $\mathrm{M}$ is the mean value, $\mathrm{m}$ is the arithmetic mean error; ${ }^{* *} \mathrm{Q}_{2}\left[\mathrm{Q}_{1}-\mathrm{Q}_{3}\right]$, where $\mathrm{Q}_{2}$ is the median $(50 \%$ of the sample), where $\mathrm{Q}_{1}$ and $\mathrm{Q}_{3}$ are the lower and upper quartiles $\left(25 \%\right.$ and $75 \%$ of the sample); ${ }^{* * *} \mathrm{Q}_{2}$ corresponds to the interval $\left[\mathrm{Q}_{1}-\mathrm{Q}_{3}\right]$.

BVDV treatment with $\mathrm{CeO}_{2}$ in concentration of $0.034 \mu \mathrm{g} / \mathrm{cm}^{3}$ before CEL cell culture monolayer infection ensured the safety of $25.0-75.0 \%$ of cells monolayer.

Visualization of data on the antiviral efficacy of the drug, which provides protection (inhibition of virus-induced CPE) in $50 \%$ of CEL cell culture monolayer $\left(\mathrm{IC}_{50}\right)$ using non-parametric KruskalWallis ANOVA analysis and median test is shown in Fig. 3.

The concentration of $\mathrm{CeO}_{2}$, which provides protection (inhibition of virus-induced $\mathrm{CPE}$ manifestation) $50 \%$ of CEL cell culture monolayer $\left(\mathrm{IC}_{50}\right)$ is $0.036 \mu \mathrm{g} / \mathrm{cm}^{3}$.

Evaluation of the inhibitory activity of $\mathrm{CeO}_{2}$ in vitro was performed according to SI, which was 2.14 for these nanoparticles.

In order to determine the effect of cerium dioxide nanoparticles on the infectious activity of BVDV, titration of the pathogen obtained after the above studies was performed. The titer of infectious activity of BVDV strain "VK-1" on CEL cell culture obtained after treatment with $\mathrm{CeO}_{2}$ was reduced compared to the control depending on the concentration of the drug (Fig. 4).

The use of cerium dioxide nanoparticles at a final concentration of $0.057 \mu \mathrm{g} / \mathrm{cm}^{3}$ under conditions of its simultaneous application with BVDV to CEL cell culture led to a decrease in the titer of infectious activity of the pathogen by $2.09 \mathrm{lg} \mathrm{TCD}_{50} / \mathrm{cm}^{3}$ compared to control. A further decrease in the concentration of $\mathrm{CeO}_{2}$ to $0.043 \mu \mathrm{g} /$ $\mathrm{cm}^{3}$ and $0.034 \mu \mathrm{g} / \mathrm{cm}^{3}$ led to a decrease in the titer of infectious activity of the pathogen by $1.31 \mathrm{lg}$ $\mathrm{TCD}_{50} / \mathrm{cm}^{3}$ and $0.87 \mathrm{lg} \mathrm{TCD}{ }_{50} / \mathrm{cm}^{3}$, respectively.

According to the results of the studies, it was determined that cerium dioxide nanoparticles when co-administered with BVDV strain "VK-1" to CEL

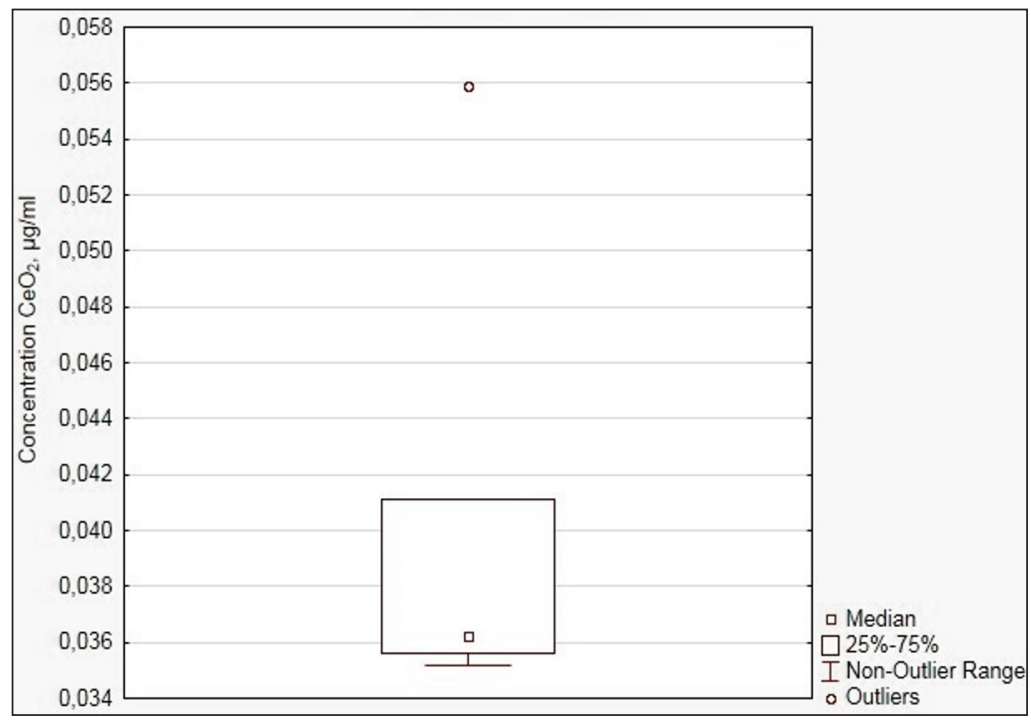

Fig. 3. Median and interquartile range of cerium dioxide $\mathrm{IC}_{50}$ on CEL cell culture, visualized by non-parametric Kruskal-Wallis ANOVA analysis and median test (boxplot) 


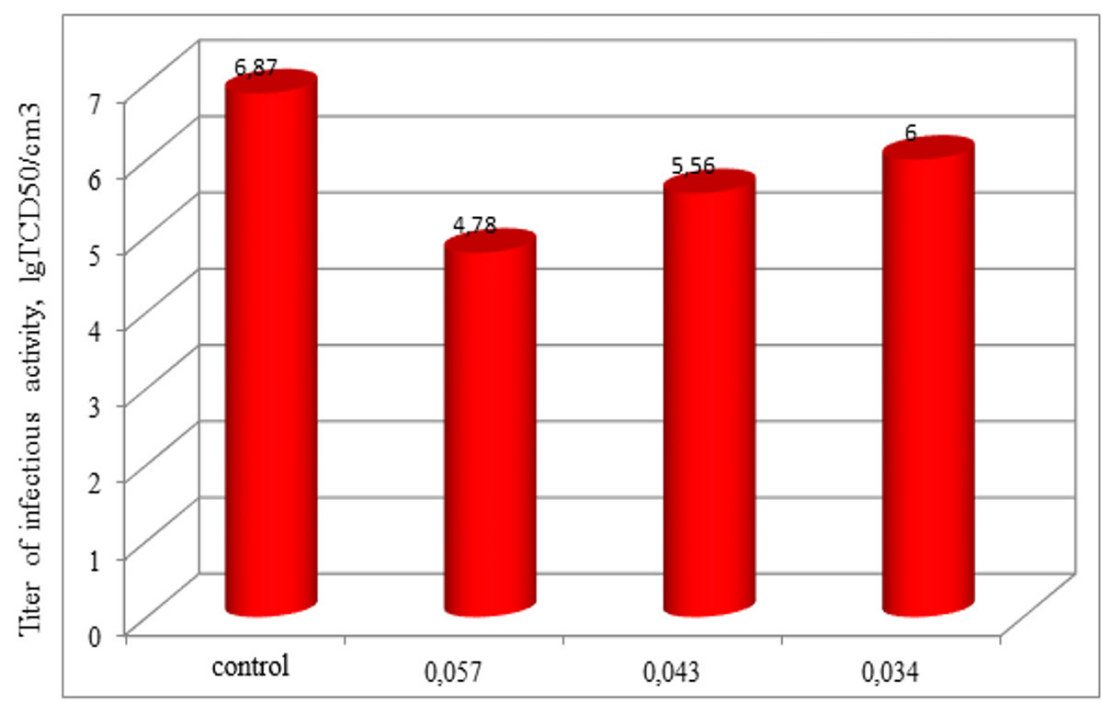

The concentration of $\mathrm{CeO} 2, \mu \mathrm{g} / \mathrm{ml}$

Fig. 4. Titer of BVDV strain "VK-1" infectious activity on the CEL cell culture after treatment with $\mathrm{CeO}_{2}$ nanoparticles

cell culture exhibit antiviral activity - inhibit virusinduced cytopathic effect and reduce infectious activity of the pathogen. Generalized results of the study of antiviral activity of cerium dioxide nanoparticles are shown in Table 3.

Conclusions. According to the results of the study, it was determined that cerium dioxide nanoparticles when co-administered with BVDV inhibit the manifestation of virus-induced $\mathrm{CPE}$ $\left(\mathrm{IC}_{50} 0.036 \mu \mathrm{g} / \mathrm{cm}^{3}\right)$ and reduce the titer of infectious activity of the pathogen by $2.09 \mathrm{lg} \mathrm{TCD}_{50} / \mathrm{cm}^{3}$.

Prospects for further research. Given the need for highly effective harmless antiviral drugs against the background of the spread of viral pathogens in humans and animals, including zoonoses, search for inorganic and organic substances is promising and requires further research. Studies have shown inhibitory effect of cerium dioxide nanoparticles on the manifestation of virus-induced cytopathic effect of bovine pestivirus in vitro and data on reducing the titer of infectious activity of the pathogen in CEL cell culture. In our opinion, the low index of selectivity calculated during the study, the optimal value of which should be $\mathrm{SI} \geq 10[34,35]$, is associated with the method of $\mathrm{CeO}_{2}$ introducing (simultaneously with the virus). Therefore, further studies of cerium nanoparticles antiviral activity should be under conditions of their introduction into the nutrient medium before and/or after infection of the cell culture with viruses [27], including bovine coronavirus.

Gratitude. The authors are grateful to employees of the Department of Molecular Epizootology, Diagnosis and Quality Control of Genetic Resources of NSC "IECVM" for assistance in conducting molecular genetic research.

\section{Table 3}

The results of the study of the $\mathrm{CeO}_{2}$ antiviral efficacy in CEL cell culture on the model of BVDV

\begin{tabular}{|l|c|c|c|c|}
\hline MAC, $\mu \mathrm{g} / \mathrm{cm}^{3}$ & ${ }^{*} \mathrm{CC}_{50}, \mu \mathrm{g} / \mathrm{cm}^{3}$ & $* \mathrm{IC}_{50}, \mu \mathrm{g} / \mathrm{cm}^{3}$ & $* *$ Titer of infectious activity, $\lg \mathrm{TCD}_{50} / \mathrm{cm}^{3}$ & SI \\
\hline 0.057 & $\begin{array}{c}0.077 \\
{[0.070-0.083]}\end{array}$ & $\begin{array}{c}0.036 \\
{[0.036-0.041]}\end{array}$ & Decrease by 2.09 & 2.14 \\
\hline
\end{tabular}

$* \mathrm{Q}_{2}\left[\mathrm{Q}_{1}-\mathrm{Q}_{3}\right]$, where $\mathrm{Q}_{2}$ is the median (50\% of the sample), $\mathrm{Q}_{1}$ and $\mathrm{Q}_{3}$ are the lower and upper quartiles $(25 \%$ and $75 \%$ of the sample), respectively; ** at $\mathrm{CeO}_{2}$ concentration of $0.057 \mu \mathrm{g} / \mathrm{cm}^{3}$. 


\section{ВИВЧЕННЯ ПРОТИВІРУСНОЇ ДІЇ ПРЕПАРАТУ НА ОСНОВІ НАНО- ЧАСТОК ДІОКСИДУ ЦЕРІЮ НА МОДЕЛІ ЗБУДНИКА ВІРУСНОЇ ДІАРЕЇ ВЕЛИКОЇ РОГАТОЇ ХУДОБИ}

Б.Т. Стегній' О.М. Корнєйков ${ }^{1}$, М.Ю. Стегній ${ }^{1}$, А.Ю. Олешко ${ }^{1}$, О.Б. Корнєйкова ${ }^{1}$, І.В. Коровін ${ }^{1}$, Л.П. Бабенко ${ }^{2}$, М.Я. Співак ${ }^{2}$

${ }^{1}$ Національний науковий центр «Інститут експериментальної і клінічної ветеринарної медицини»,

вул. Пушкінська, 83, Харків, 61083, Україна

${ }^{2}$ Інститут мікробіології і вірусологї ім. Д.К. Заболотного НАН України, вул. Академіка Заболотного, 154, Київ, 03143, Україна

\section{Резюме}

Наночастки оксиду церію $\left(\mathrm{CeO}_{2}\right)$ мають широкий спектр біологічних властивостей, в т.ч. противірусну активність. Препарати на основі наночасток оксиду церію можуть бути ефективні проти РНК-вірусів тварин, які мають найбільше епізоотичне значення для України та потенцій-

1. SARS (Severe acute respiratory syndrome). National Health Service (England), reviewed 24.10.2019. https://www.nhs.uk/conditions/sars/

2. Middle East respiratory syndrome coronavirus (MERS-CoV) - Disease outbreak news. World Health Organization. https://www.who.int/csr/ don/archive/disease/coronavirus_infections/en/

3. Coronavirus (COVID-19): Overview. World Health Organization. https://covid19.who.int/

4. Yu B, Li C, Chen P, et al. Low dose of hydroxychloroquine reduces fatality of critically ill patients with COVID-19 [published online ahead of print, 2020 May 15]. Sci China Life Sci. 2020; 1-7. doi:10.1007/s11427-020-1732-2

5. Yang Q, Xie L, Zhang W, et al. Analysis of the clinical characteristics, drug treatments and prognoses of 136 patients with coronavirus disease 2019 [published online ahead of print, 2020 May 25]. J Clin Pharm Ther. 2020;10.1111/ jcpt.13170. doi:10.1111/jcpt.13170

6. Tykhonova EP, Kuzmyna TIu, Andronova NV, y dr. Yzuchenye эffektyvnosty protyvovyrusnыkh preparatov (umyfenovyra, tryazavyryna) $\mathrm{v}$ otnoshenyy ostrukh respyratornыkh vyrusnыkh но проти вірусів людини, в т.ч. SARS-CoV-2. В наших дослідженнях визначали дію наночасток оксиду церію на вірус вірусної діареї великої рогатої худоби (ВД ВРХ) - пестівірус, який $\epsilon$ етіологічним агентом вірусної діареї ВРХ. Для визначення противірусної ефективності $\mathrm{CeO}_{2}$ використовували цитопатогенний штам вірусу ВД «ВК-1» як етіологічний агент ВД ВРХ, який індукує прояв цитопатичного ефекту на перещеплюваній культурі легенів ембріону корови. При оцінці противірусної ефективності $\mathrm{CeO}_{2}$ визначено, що ГДК для перещеплюваної культури клітин ЛЕК становить 0,057 мкг $/ \mathrm{cm}^{3}$, a $\mathrm{CC}_{50}$ сполуки дорівнює 0,077 мкг $/ \mathrm{cm}^{3}$. Противірусну активність $\mathrm{CeO}_{2}$ оцінювали за показником $\mathrm{IC}_{50}$, який становив 0,036 мкг $/ \mathrm{cm}^{3}$ та індексом селективності, який при одночасному внесенні наноцерію з вірусом ВД ВРХ дорівнював 2,14. Відмічено зниження титру інфекційної активності вірусу при обробці $\mathrm{CeO}_{2}$ на 2,09 $\lg$ ТЦД ${ }_{50 / \mathrm{cm}}{ }^{3}$.

Ключові слова: Вірус, діарея великої рогатої худоби, наночастки, оксид церію, перещеплювана культура клітин легенів ембріону корови, противірусна активність.

ynfektsyi. Kazanskyi medytsynskyi zhurnal. 2018; 9 (2):215-223. doi: 10.17816/KMJ2018215. Russian.

7. Ekins S, Lingerfelt MA, Comer JE, et al. Efficacy of Tilorone Dihydrochloride against Ebola Virus Infection. Antimicrob Agents Chemother. 2018; 62(2):e01711-17. Published 2018 Jan 25. doi:10.1128/AAC.01711-17

8. Ogbole OO, Akinleye TE, Segun PA, et al. In vitro antiviral activity of twenty-seven medicinal plant extracts from Southwest Nigeria against three serotypes of echoviruses. Virol J. 2018; 15:110. https://doi.org/10.1186/s12985-0181022-7

9. Chaohong Liu, Yun Wang, Chunchen Wu, Rongjuan Pei, Jianhua Song, Shiyun Chen, Xinwen Chen. Dioscin's antiviral effect in vitro.Virus Research. 2013; 172 (1-2):9-14. https://doi. org/10.1016/j.virusres.2012.12.001

10. Gómez-García Manuel, Puente Héctor, Argüello Héctor, Mencía-Ares Óscar, Rubio Pedro, Carvajal Ana. In vitro Assessment of Antiviral Effect of Natural Compounds on Porcine Epidemic Diarrhea Coronavirus. Frontiers in Vet- 
erinary Science. 2021; 8:261. doi https://doi. org/10.3389/fvets.2021.652000

11. Karimi A, Moradi MT, Saeedi M, Asgari S, Rafieian-Kopaei M. Antiviral activity of Quercus persica L.: High efficacy and low toxicity. Adv Biomed Res. 2013; 2:36. Published 2013 Mar 30. doi:10.4103/2277-9175.109722

12. Taylor JD, Fulton RW, Lehenbauer TW, Step DL, Confer AW. The epidemiology of bovine respiratory disease: What is the evidence for predisposing factors? Can Vet J. 2010; 51(10):1095-1102.

13. Larson RL. Bovine Viral Diarrhea Virus-Associated Disease in Feedlot Cattle. Vet Clin North Am Food Anim Pract. 2015; 31(3):367-80. vi. doi: 10.1016/j.cvfa.2015.05.007. Epub 2015 Jul 22. PMID: 26210765.

14. J Susilo, J Siswanto, T Fadrial Karmil, Rusli Rusli, M Nur Salim, Zainuddin Zainuddin, Ginta Riady, Dasrul Dasrul, Fakhrurrazi Fakhrurrazi, Azhari Azhari, Andi Novita. The Role of Bovine Viral Diarrhea Virus in Bovine Respiratory Disease Complex in Cattle Import Livestock At 2019 Periode. Jurnal Medika Veterinaria. 2020; 14 (1):61-67. 10.21157/j.med.vet.v14i1. 17402

15. Matiluz Doria-Ramos, Teresa Oviedo-Socarras, Misael Oviedo-Pastrana, Diego Ortiz-Ortega. Seroprevalence of viral agents of the Bovine Respiratory Complex in Creole breeds of the Turipaná Research Center of AGROSAVIA. Rev Mex Cienc Pecu. 2020;11(3):771-782. https://doi. org/10.22319/rmcp.v11i3.5154

16. Zhang SQ, Guo BTL, Wang FX, Zhu HW, Wen YJ, Cheng S. Genetic diversity of bovine viral diarrhea viruses in commercial bovine serum batches of Chinese origin. Infection Genetics and Evolution. 2014; 27:230-233. doi: 10.1016/j. meegid.2014.07.021

17. Hlotov AH, Hlotova TY, Koteneva SV. O kontamynatsyy ymportyruemoi fetalnoi sыvorotky krovy krupnoho rohatoho skota pestyvyrusamy kak faktore rasprostranenyia vyrusnoi dyarey v uslovyiakh hlobalyzatsyy: myny-obzor. Selskokhoziaistvennaia byolohyia. 2018; 53 (2):248-257. https://doi.org/10.15389/agrobiology.2018.2.248rus. Russian.

18. Scharnböck B, Roch FF, Richter V, et al. A meta-analysis of bovine viral diarrhoea virus
(BVDV) prevalences in the global cattle population. Sci Rep. 2018; 8:14420. https://doi. org/10.1038/s41598-018-32831-2

19. Peterhans E, Bachofen C, Stalder H, Schweizer M. Cytopathic bovine viral diarrhea viruses (BVDV): emerging pestiviruses doomed to extinction. Veterinary research. 2010; 41(6):44. https://doi.org/10.1051/vetres/2010016

20. Paul H Walz, Manuel F Chamorro, Shollie M Falkenberg, Thomas Passler, Frank van der Meer. Bovine viral diarrhea virus: An updated American College of Veterinary Internal Medicine consensus statement with focus on virus biology, hosts, immunosuppression, and vaccination. J Vet Intern Med. 2020; 34:1690-1706. https:// doi.org/10.1111/jvim.15816

21. Khodakaram-Tafti A, Farjanikish GH. Persistent bovine viral diarrhea virus (BVDV) infection in cattle herds. Iran J Vet Res. 2017; 18(3):154-163.

22. Hlotov AH, Hlotova TY, Semenova OV, Koteneva SV, Serheev AA, Serheev AN. Patohennost yzoliatov razlychnыkh byotypov vyrusa vyrusnoi dyarey bolezny slyzystыkh obolochek dlia seronehatyvnыkh teliat. Rossyiskyi veterynarnыi zhurnal. 2015; 1:19-22. Russian.

23. Metodycheskye rekomendatsyy po yzuchenyiu kulturalnыkh, antyhennыkh, henetycheskykh svoistv y ynfektsyonnoi aktyvnosty proyzvodstvennыkh у эрyzootycheskykh shtammov koronavyrusa krupnoho rohatoho skota. RUP «YЭV ym. S.N. Vыshelesskoho». 2016; 22 p. Russian.

24. Polimerazna lantsiuhova reaktsiia u praktytsi veterynarnoi medytsyny ta biolohichnykh doslidzhenniakh. Stehnii BT, Herilovych AP, Lymanska OIu, ta inshi. Naukovo-metodychnyi posibnyk. Kharkiv. 2010; 227 s. Ukrainian.

25. Kliučinskas, Rolanas \& Lukauskas, Kazimieras \& Milius, Jonas \& Vyšniauskis, Gintautas \& Kliučinskas, Deividas \& Salomskas, Algirdas. Detection of bovine viral diarrhoea virus in saliva samples. Bulletin Veterinary Institute in Pulawy. 2008; 52:31-37.

26. Siuryn VN, Belousova BN, Fomyna NV. Veterynarna virusolohiia. M.: Kolos. 1984:376 s. Ukrainian.

27. Aoki-Utsubo C, Chen M, Hotta H. Time-of-addition and Temperature-shift Assays to Determine 
Particular Step(s) in the Viral Life Cycle that is Blocked by Antiviral Substance(s). Bio-protocol. 2018; 8(9):e2830. doi: 10.21769/BioProtoc. 2830

28. Skrotska OI, Zholobak NM, Antonenko SV, Spivak MIa, Karpov O.V. Protyherpetychna diia molekuliarnoho kompleksu RNK-tyloron u kulturi klityn. Mikrobiol Zh. 2007; 69 (3):62-68. Ukrainian.

29. Shemendiuk OV, Zholner LH, Zholobak NM, Spivak MIa.Antyvirusna y interferonindukuiucha diia aminoetokydyfeniliv. Naukovi visti NTUU «KPI». 2015; 3:84-90. Ukrainian.

30. Guidance for Industry Antiviral Product Development - Conducting and Submitting Virology Studies to the Agency. Center for Drug Evaluation and Research (CDER). https://www.fda.gov/ media/71223/download

31. Hlants S. Medyko-byolohycheskaia statystyka. Per. s anhl. M: Praktyka. 1999:459 s. Russian.

32. Sara Boslaf. Statystyka dlia vsekh. Per. s anhl. Volkova P.A, Fliamer YM, Lyberman MV, Ha- lytsыna AA. M.: DMK Dress. 2015:586 s. Russian.

33. Quest Graph ${ }^{\mathrm{TM}}$ IC50 Calculator." AAT Bioquest, Inc, 01 Sep. 2021. https://www.aatbio.com/tools/ ic50-calculator

34. Peña-Mora'n OA, Villarreal ML, A'lvarez-Berber L, Meneses-Acosta A, Rodri'guez-Lo'p V. Cytotoxicity, post-treatment recovery, and selectivity analysis of naturally occurring podophyllotoxins from Bursera fagaroides var. fagaroides on breast Cancercell lines. Molecules. 2016; 21:1013. https://doi.org/10.3390/molecules 21081013 .

35. Awouafack MD, McGaw LJ, Gottfried S, Mbouangouere R, Tane P, Spiteller M, Eloff JN. Antimicrobial activity and cytotoxicity of the ethanol extract, fractions and eight compounds isolated from Eriosema robustum (Fabaceae). BMC Complement Altern Med. 2013; 13:289. https://doi. org/10.1186/1472-6882-13-289.

Received 27.10.2021 